\title{
Hepatocyte growth factor stimulates proliferation of pancreatic $\beta$-cells particularly in the presence of subphysiological glucose concentrations
}

\author{
S Gahr, M Merger, L C Bollheimer, C G Hammerschmied, J Schölmerich \\ and S R Hügl \\ Department of Internal Medicine I, University of Regensburg, F J-Strauß-Allee 11, 93042 Regensburg, Germany \\ (Requests for offprints should be addressed to S R Hügl, Wiener Ring 97, 97084 Würzburg, Germany; Email: sigrun.huegl@planet-interkom.de)
}

\begin{abstract}
We investigated the role of hepatocyte growth factor (HGF) in $\beta$-cell growth and its complex intracellular signal transduction pathways. Cell proliferation was measured in the $\beta$-cell line INS-1 using $\left[{ }^{3} \mathrm{H}\right]$ thymidine incorporation. Activation of mitogenic signaling proteins was assessed using co-immunoprecipitation, immunoblot analysis and specific protein activity inhibitors in proliferation assays. HGF (1.375 nM) increased INS-1 cell proliferation in the presence of 3-24 mM glucose up to 45-fold vs unstimulated controls. HGF exceeded the effect of glucose alone (2.2-fold at $3 \mathrm{mM}$ glucose and 1.7-fold in the presence of $15 \mathrm{mM}$ glucose). The HGF-induced INS-1 cell proliferation was further increased by addition of IGF-I or GH. Stimulation with HGF activated the JAK-2/STAT-5 pathway with a subsequent activation of phosphatidylinositol-3'-kinase (PI3'K). PI3'K activation was necessary for HGF- and glucosestimulated INS-1 cell proliferation. The effect of PI3'K was mediated via $70 \mathrm{kDa}$ S6 kinase and protein kinase $B$, which showed maximum activation in the presence of 3-6 mM glucose. Protein kinase $C$ was essential for HGF-induced INS-1 cell proliferation. The HGF effect was also mediated at low glucose concentrations via insulin receptor substrate 4 (IRS-4) whereas other IRS proteins did not show any activation. High glucose concentrations also showed an increased IRS-4/PI3'K binding and therefore activation. In conclusion, $\beta$-cell proliferation is mediated via complex interacting signal transduction pathways. HGF, in contrast to other growth factors, seems to be of importance particularly in the presence of low glucose concentrations and therefore takes a special role in this complex concert.
\end{abstract}

Journal of Molecular Endocrinology (2002) 28, 99-110

\section{Introduction}

The insulin-producing $\beta$-cells of the pancreatic islets are well-differentiated and consequently have a low mitotic index (Brockenbrough et al. 1988, Swenne 1992). Under normal conditions only $0 \cdot 5 \%$ are undergoing mitosis (Brockenbrough et al. 1988). However, in certain clinical states, e.g. pregnancy and obesity, the $\beta$-cell proliferation rate can be considerably higher. Recent studies have revealed that nutrients such as amino acids or glucose in a physiologically relevant range $(6-18 \mathrm{mM}$ glucose) or changes in electrolyte concentrations (e.g. calcium ions) can instigate a marked increase in $\beta$-cell mitosis (Chick 1973, Swenne 1992, Hügl et al. 1998), whereas an inhibitory effect on $\beta$-cell mitosis has been seen in the presence of free fatty acids
(Cousin et al. 2001). The regulation of mitogenesis in pancreatic $\beta$-cells seems to be even more complex than in other eukaryotic cells due to the unique characteristic that the stimulus-coupling mechanisms of the $\beta$-cell are tightly linked to its metabolic state (Newgard \& McGarry 1995, Prenki 1996).

Certain growth factors, in particular insulin-like growth factor (IGF-I) and growth hormone (GH), have been shown to enhance the number of replicating $\beta$-cells in rodent islets from $0.5 \%$ up to 6\% (Nielsen et al. 1989, Billestrup \& Nielsen 1991, Swenne 1992). Both IGF-I and GH stimulate $\beta$-cell proliferation glucose-dependently, but are using different, not completely understood signal transduction pathways mediating $\beta$-cell proliferation (Hügl et al. 1998, 1999). On the other hand, 
glucose itself is able to induce activation of the signaling proteins Erk1/2 and $70 \mathrm{kDa}$ S6 kinase $\left(\mathrm{p} 70^{\mathrm{S} 6 \mathrm{~K}}\right)$ independently of growth factors (Hügl et al. 1998). IGF-I stimulates $\beta$-cell proliferation mainly via tyrosine autophosphorylation activation of the IGF-I-receptor tyrosine kinase, which results in downstream tyrosine phosphorylation of insulin receptor substrate-2 (IRS-2) and SH2containing protein (Shc), and a consecutive activation of phosphatidylinositol-3'-kinase (PI3'K), protein kinase $\mathrm{B}(\mathrm{PKB})$, the mammalian target of rapamycin, and p70 ${ }^{\mathrm{S} 6 \mathrm{~K}}$ (Hügl et al. 1998, Dickson et al. 2001). The proliferative effect of $\mathrm{GH}$ is mediated via the activation of the Janus kinase2 (JAK-2) and the subsequent activation of the signal transducer and activator of transcription-5 (STAT-5) (Hügl et al. 1999).

Both growth factors, IGF-I and GH, stimulate $\beta$-cell growth independently and show a synergistic effect. There is no proof for any crosstalk between the JAK-2/STAT-5 and the IRS-2 pathway. Apparently, glucose metabolism is necessary to obtain the proliferative effect of IGF-I and GH (Hügl et al. 1998, 1999). Glucose mediates hereby the activation of protein kinase $\mathrm{G}(\mathrm{PKG})$ (Welsh et al. 1993, Hügl et al. 1998) and the elevation of $\mathrm{Ca}^{2+}$ and cAMP (Chick 1973, Swenne 1992, Frodin et al. 1995). Experiments with IRS-1 and IRS-2 knockout mice (IRS-1 ${ }^{-/}$, IRS-2 $^{-/-}$) support these findings: IRS-1 ${ }^{-/}$mice showed no significant decrease in $\beta$-cell mass and $\beta$-cell proliferation, whereas IRS-2 ${ }^{-/-}$mice developed a severe lack of $\beta$-cell mass and stimulation of $\beta$-cell growth by IGF-I was not possible (Withers et al. 1998, 1999).

Intriguingly, another important mitogen signal transduction protein, the mitogen-activated protein kinase (MAPK), seems to be of minor importance in pancreatic $\beta$-cell proliferation. Only in the presence of low, subphysiological glucose concentrations was some activation detectable (Hügl et al. 1998, 1999, Dickson et al. 2001). But still the signal transduction pathways involved and their complex interactions are not fully resolved.

Besides IGF-I and GH, hepatocyte growth factor (HGF) is known to induce cell growth. HGF hereby activates the PI3'K and the MAPK signal transduction pathways (Boylan \& Gruppuso 1998, Jehle et al. 1998, To \& Tsao 1998). HGF is also known to stimulate islet cell proliferation, but most of the experiments were done in fetal islets
(Otonkoski et al. 1994, 1996, Beattie et al. 1996, 1997). But also in adult islet cells increased proliferation in the presence of HGF was seen (Hayek et al. 1995, Vila et al. 1995). Even more overexpression of HGF showed a marked increase in $\beta$-cells (Garcia-Ocana et al. 2000), but the effect of $\mathrm{HGF}$ on mitogen signal transduction pathways in pancreatic $\beta$-cells is still not completely understood.

In our experiments we used the well-differentiated $\beta$-cell line INS-1. INS-1 cells secrete insulin, glucose-dependently (Asfari 1992), and show a somewhat higher mitotic index than primary islets cells. The proliferation of this cell line is stimulated by nutrients and several growth factors (Hügl et al. 1998, 1999). So the INS-1 cell is a well-defined, convenient model to study the proliferation of pancreatic $\beta$-cells. The aim of the following experiments was to get a deeper insight in the complex mechanisms which activate the proliferation of pancreatic $\beta$-cells and to find out how different growth factors like HGF, IGF-I and GH interact in terms of mitogen transduction pathways.

\section{Materials and methods}

\section{Materials}

[Methyl- ${ }^{3} \mathrm{H}$ ] thymidine $(20 \mathrm{Ci} / \mathrm{mmol})$ was from NEN (Boston, MA, USA). IGF-I, HGF and all protein activity inhibitors were purchased from Calbiochem-Novabiochem (La Jolla, CA, USA). Anti-phospho-MAPK antiserum was from Promega Corp. (Madison, WI, USA), anti-IRS-1 and -2 antisera were a gift from Dr M Myers (Joslin Diabetes Center, Boston, MA, USA), all the other antisera were purchased from Upstate Biotechnology (Lake Placid, NY, USA). Transblot nitrocellulose membrane $(0.45 \mu \mathrm{m}$ pore size) was from Biorad (Hercules, CA, USA), and the chemiluminescence detection kit (ECL+) from Amersham International (Amersham, Bucks, UK). All the other chemicals were purchased from Sigma Chemical Co. (Deisenhofen, Germany) or Merck (Darmstadt, Germany) and were of the highest purity available.

\section{Cell culture}

All experiments were carried out using the glucose-sensitive pancreatic cell line INS-1 (Asfari 
1992). The INS- 1 cells were maintained at $37^{\circ} \mathrm{C}$ in $5 \% \mathrm{CO}_{2}$ in RPMI 1640 medium containing $50 \mu \mathrm{M}$ $\beta$-mercaptoethanol, $1 \mathrm{mM}$ sodium pyruvate, $2 \mathrm{mM}$ L-glutamine, $10 \%$ fetal calf serum, $11.2 \mathrm{mM}$ glucose, 100 units $/ \mathrm{ml}$ penicillin and $100 \mu \mathrm{g} / \mathrm{ml}$ streptomycin as described (Asfari 1992) and were subcultured at $80 \%$ confluence.

\section{$\left[{ }^{3} \mathrm{H}\right]$ Thymidine incorporation}

Thymidine incorporation was used to quantify INS-1 cell proliferation (Hofmann et al. 1989, Frodin et al. 1995). $\left[{ }^{3} \mathrm{H}\right]$ Thymidine incorporation was more suited for INS-1 cell proliferation than other methods such as cell number counting because INS-1 cells grow adherently and are not easy to separate to get quantitatively representative data. INS- 1 cells $\left(10^{5} /\right.$ well $)$ were subcultured in 96-well plates and incubated for $48 \mathrm{~h}$ at $37^{\circ} \mathrm{C}$ in $5 \% \mathrm{CO}_{2}$ in RPMI 1640 medium containing $50 \mu \mathrm{M}$ $\beta$-mercaptoethanol, $1 \mathrm{mM}$ sodium pyruvate, $2 \mathrm{mM}$ L-glutamine, $10 \%$ fetal calf serum, $11.2 \mathrm{mM}$ glucose, 100 units $/ \mathrm{ml}$ penicillin and $100 \mu \mathrm{g} / \mathrm{ml}$ streptomycin as described. The medium was then replaced by RPMI 1640 with $0 \cdot 1 \%$ BSA instead of serum and no glucose and the cells starved for $24 \mathrm{~h}$. Cell growth was then stimulated for $24 \mathrm{~h}$ at $37^{\circ} \mathrm{C}$ in $5 \% \quad \mathrm{CO}_{2}$ by different glucose concentrations $(0-24 \mathrm{mM})$ with or without $\mathrm{HGF}$ and with or without various protein activity inhibitors. $\left[{ }^{3} \mathrm{H}\right]$ Thymidine $(5 \mu \mathrm{Ci} / \mathrm{ml})$ was added for the last $4 \mathrm{~h}$ of this incubation period to assess the proliferation rate of the INS-1 cells. The cells were then lysed using a semiautomatic cell harvester (Inotech, Basel, Switzerland) and the lysates transferred to glass fiber micropore filters (Packard, Meriden, CT, USA). The INS-1 cell DNA was trapped on the filters and the incorporated $\left[{ }^{3} \mathrm{H}\right]$ thymidine counted by liquid scintillation counting. All experiments were done in triplicates; data are presented as means \pm S.E. of at least five independent experiments. Statistically significant differences between groups were analyzed using Student's $t$-test; $P<0 \cdot 05$ was considered statistically significant.

\section{Protein preparation}

INS-1 cells were subcultured in $10 \mathrm{~cm}$ dishes to about 50\% confluence and made quiescent by glucose and serum deprivation as described before.
The cells were then incubated in fresh RPMI 1640 medium containing $0-24 \mathrm{mM}$ glucose with or without 1.375 nM HGF for 5-60 min and the cells then lysed in $0.5 \mathrm{ml}$ of ice-cold lysis buffer $(50 \mathrm{mM}$ Hepes, pH 7.5, 1\% (v/v) Nonidet P40, 2 mM sodium vanadate, $50 \mathrm{mM}$ sodium fluoride, $10 \mathrm{mM}$ sodium pyrophosphate, $4 \mathrm{mM}$ EDTA, $10 \mu \mathrm{M}$ leupeptin, $10 \mu \mathrm{g} / \mathrm{ml}$ aprotinin and $100 \mu \mathrm{M}$ phenylmethylsulfonyl fluoride) as described previously (Cheatham et al. 1994, Myers et al. 1994). Cell lysates were stored at $-80{ }^{\circ} \mathrm{C}$. Protein assays were done using the bicinchoninic acid method (Pierce, Rockford, IL, USA).

\section{Protein immunoblot and co-immunoprecipitation analysis}

Mitogenic signal transduction protein expression and protein tyrosine phosphorylation were tested using immunoblot analysis, stimulated proteinprotein interactions between mitogenic signal transduction proteins using co-immunoprecipitation analysis as described previously (Cheatham et al. 1994, Myers et al. 1994). A horseradish peroxidasebased chemiluminescence reaction was used as the secondary detection method. Fifty to seventyfive micrograms of INS-1 cell total protein lysate were used for immunoblot analysis, $750 \mu \mathrm{g}$ for coimmunoprecipitation analysis.

\section{Results}

\section{HGF stimulates INS-1 cell proliferation in the presence of physiological and especially of subphysiological glucose concentrations}

The effect of different glucose concentrations $(0-24 \mathrm{mM})$ and HGF $(1375 \mathrm{nM})$ on INS-1 cell proliferation was determined by $\left[{ }^{3} \mathrm{H}\right]$ thymidine incorporation. INS-1 cells were used as a model to examine pancreatic $\beta$-cell proliferation as they respond, unlike the majority of other pancreatic $\beta$-cell lines, to glucose in the physiologically relevant range $(6-18 \mathrm{mM}$ glucose) in terms of insulin secretion (Asfari 1992) and cell proliferation (Hügl et al. 1998, 1999). INS-1 cells show a somewhat higher mitotic index than pancreatic $\beta$-cells and other slower-growing glucose-responsive $\beta$-cell lines and are therefore a convenient tool to 
generate information on the proliferation of differentiated pancreatic $\beta$-cells, even if the results should be interpreted with some reservation as insulinoma-derived cell lines always show a degree of aberrant growth control. As demonstrated previously (Hügl et al. 1998, 1999) glucose induced INS- 1 cell proliferation up to 30 -fold measured by $\left[{ }^{3} \mathrm{H}\right]$ thymidine incorporation, compared with unstimulated controls, in a dose-dependent manner. Maximal stimulation was seen at $8 \mathrm{mM}$ glucose (Fig. 1). Addition of HGF showed an increase in INS-1 cell proliferation up to 45-fold compared with unstimulated controls (Fig. 1). HGF was hereby able to stimulate INS-1 cell proliferation even in the presence of subphysiological glucose concentrations and augmented the effect of glucose alone $2 \cdot 2$-fold at $3 \mathrm{mM}$ glucose. The maximum effect of HGF-induced INS-1 cell proliferation was seen in the presence of $8 \mathrm{mM}$ glucose $+1.375 \mathrm{nM}$ HGF, but the additional effect of HGF over stimulation with glucose alone was only $1 \cdot 5$-fold. In a series of dose-finding experiments (data not shown), HGF showed the optimum effect at very low concentrations. The best results were seen at $1 \cdot 375 \mathrm{nM}$ HGF. Higher concentrations (up to $275 \mathrm{nM}$ HGF) did not yield a better proliferation rate (data not shown). So subsequently $1.375 \mathrm{nM}$ HGF was used as the standard concentration in all following experiments. Insulin secretion in these cells was thereby increased $(1532 \mathrm{ng} / \mathrm{mg}$ total protein in $\mathrm{HGF}+$ glucose-stimulated cells vs $997 \mathrm{ng} / \mathrm{mg}$ in glucose-only-stimulated INS-1 cells), demonstrating that HGF-stimulated cells show no sign of dedifferentiation.

The glucose- and dose-dependent stimulating effect of HGF showed similarities to that instigated by IGF-I or GH (Hügl et al. 1998, 1999). However, coincubation of INS-1 cells with HGF+IGF-I and $\mathrm{HGF}+\mathrm{GH}$ revealed distinct differences; INS-1 cells instigated with $\mathrm{HGF}+\mathrm{IGF}-\mathrm{I}$ showed an increase of $\left[{ }^{3} \mathrm{H}\right]$ thymidine incorporation up to $1 \cdot 7$-fold, which was significant, especially in the presence of glucose concentrations $>12 \mathrm{mM} \quad(P<0 \cdot 05$, Fig. 2). Coincubation of INS-1 cells with HGF and GH as well showed an increase in cell proliferation up to 1.7-fold, but this time the increase above HGF alone was significant only in the presence of low glucose concentrations up to $9 \mathrm{mM}(P<0 \cdot 05$, Fig. $2)$. In the presence of higher glucose concentrations this effect was still seen as a trend, but it was not significant ( $P>0 \cdot 05$, Fig. 2).

\section{The effects of various protein phosphorylation inhibitors on glucose- and HGF-stimulated INS-1 cell proliferation}

The effect of different specific protein kinase and phosphatase inhibitors on INS-1 cell proliferation in the presence of $15 \mathrm{mM}$ glucose with or without $1.375 \mathrm{nM}$ HGF was examined using $\left[{ }^{3} \mathrm{H}\right]$ thymidine incorporation (Table 1). In these series of experiments $15 \mathrm{mM}$ glucose increased $\left[{ }^{3} \mathrm{H}\right]$ thymidine incorporation about 20-fold compared with equally treated cells in the absence of glucose $(P<0.001)$, whereas the combination of $15 \mathrm{mM}$ glucose and $1.375 \mathrm{nM}$ HGF augmented $\left[{ }^{3} \mathrm{H}\right]$ thymidine incorporation in INS- 1 cells about 35 -fold $(P<0.001)$ compared with unstimulated controls as described previously (Fig. 1).

Addition of wortmannin $(10 \mathrm{nM})$, a specific inhibitor of PI3'K activity (Ogreid et al. 1994), significantly reduced $15 \mathrm{mM}$ glucose-stimulated INS-1 cell proliferation by $90 \%(P<0 \cdot 001$, Table 1$)$ and proliferation stimulated by $15 \mathrm{mM}$ glucose + $1 \cdot 375 \mathrm{nM}$ HGF by $75 \%(P<0 \cdot 001$, Table 1$)$.

Rapamycin is a specific inhibitor of $\mathrm{p} 70^{\mathrm{S} 6 \mathrm{~K}}$, which is activated downstream of PI3'K (Kardalinou et al. 1994). Rapamycin (10 nM) added to INS-1 cells stimulated with $15 \mathrm{mM}$ glucose reduced $\left[{ }^{3} \mathrm{H}\right]$ thymidine incorporation by $60 \% \quad(P<0 \cdot 001)$, whereas INS-1 cells stimulated with $15 \mathrm{nM}$ glucose $+1.375 \mathrm{nM}$ HGF showed a reduction by $50 \%(P<0 \cdot 001)$ (Table 1$)$.

Apparently, PI3'K-mediated proliferation in INS-1 cells uses different signal transduction pathways. Inhibition of MEK, the activator of MAPK, by PD98059 (50 $\mu \mathrm{M})$ (Pang et al. 1995) did not change the proliferation rate of INS-1 cells significantly either in the presence of glucose $(P=0.3)$ or in the presence of glucose + HGF $(P=0 \cdot 4)$ (Table 1). This suggests that the MAPK pathway plays no important role in the HGFmediated INS-1 cell proliferation.

Inhibition of PKC by sphingosine $(10 \mu \mathrm{M})$ (Liu 1996) resulted in about $57 \%$ reduction of HGF-stimulated $\quad\left[{ }^{3} \mathrm{H}\right]$ thymidine incorporation $(P<0.001)$ (Table 1). Besides inhibiting PKC, staurosporine also inhibits protein kinase $\mathrm{G}(\mathrm{PKG})$ and protein kinase A (PKA) (Sjoholm 1997) but had no additional inhibitory effect compared with sphingosine (Table 1). These findings give some hint that certain $\mathrm{PKC}$ isoforms might be involved in the regulation of HGF-mediated INS-1 cell 

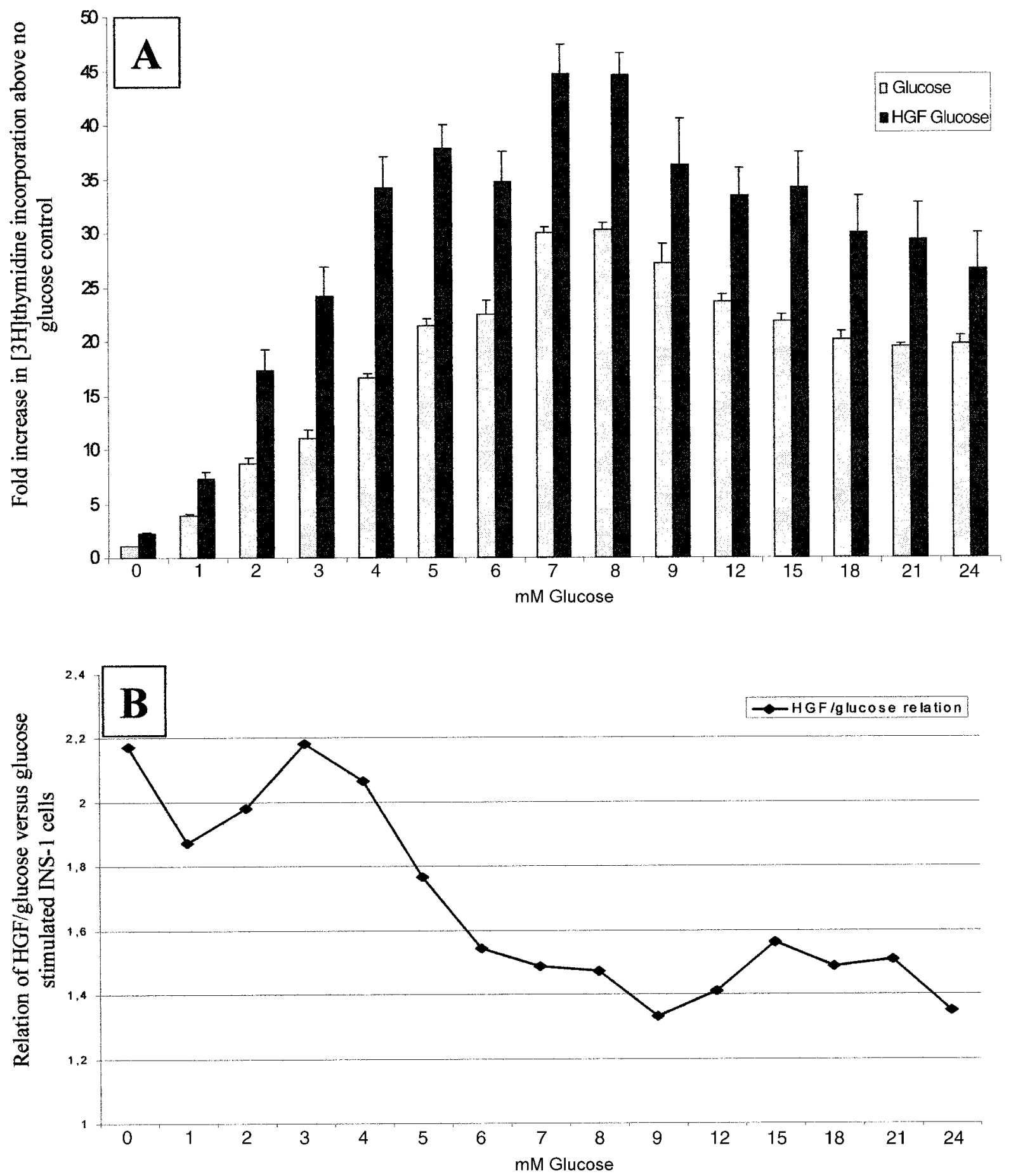

Figure $1\left[{ }^{3} \mathrm{H}\right]$ Thymidine incorporation in INS-1 cells with different glucose concentrations. (A) Approximately $10^{5}$ quiescent INS-1 cells/well were incubated for $24 \mathrm{~h}$ in RPMI 1640 medium containing $0.1 \%$ BSA and 0-24 mM glucose with or without $1.375 \mathrm{nM}$ hepatocyte growth factor (HGF), then assessed for proliferation rate by $\left[{ }^{3} \mathrm{H}\right]$ thymidine incorporation as described in Materials and methods. All experiments were done in triplicates on at least eight independent occasions. Data are presented as $x$-fold increase above the control observation in the absence of glucose and HGF (i.e. $3000-4000$ c.p.m. $/ 10^{5}$ cells), depicted as means \pm s.E. $(n \geq 8)$. (B) Relative increase in $\left[{ }^{3} \mathrm{H}\right]$ thymidine incorporation in HGF-stimulated INS-1 cells at different glucose concentrations vs glucose-only-stimulated cells. 


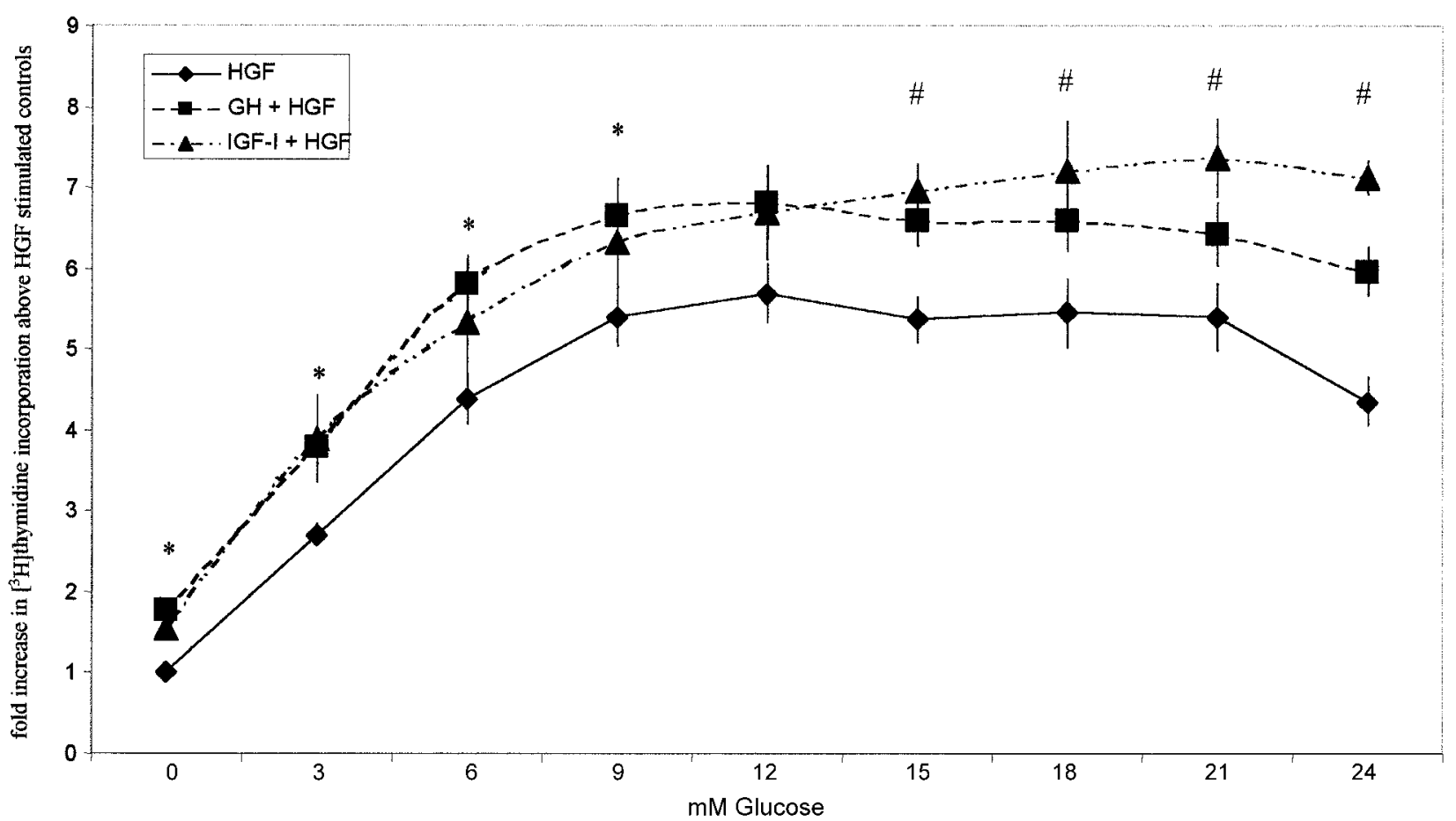

Figure $2\left[{ }^{3} \mathrm{H}\right]$ Thymidine incorporation in INS-1 cells stimulated with $1.375 \mathrm{nM}$ HGF with or without additional growth factors. Approximately $10^{5}$ quiescent INS-1 cells/well were incubated for $24 \mathrm{~h}$ in RPMI 1640 medium containing $0 \cdot 1 \%$ BSA, 0-24 mM glucose and 1.375 nM HGF with or without $10 \mathrm{nM}$ IGF-I or $1.375 \mathrm{nM}$ HGF with or without $10 \mathrm{nM}$ GH, then assessed for proliferation rate by $\left[{ }^{3} \mathrm{H}\right]$ thymidine incorporation as described in Materials and methods. All experiments were done in triplicate on at least five independent occasions. Data are presented as $x$-fold increase above the control observation in the presence of $1.375 \mathrm{nM} \mathrm{HGF}$, depicted as means \pm S.E. $(n \geq 5)$. *Significant increase in proliferation of cells stimulated with $\mathrm{GH}+\mathrm{HGF}$ vs HGF-stimulated controls; \#significant increase in proliferation of cells stimulated with IGF-I+HGF $(P<0.05)$.

proliferation as well as in the glucose-stimulated cell proliferation.

Intracellular $\mathrm{Ca}^{2+}$ concentration is essential for cell proliferation (Frodin et al. 1995, Khoo \& Cobb 1997). In our experiments we used calmidazolium $(50 \mathrm{nM})$ to inhibit $\mathrm{Ca}^{2+}$ / calmodulin-dependent proteins, which reduced $\left[{ }^{3} \mathrm{H}\right]$ thymidine incorporation in INS-1 cells stimulated with $\mathrm{HGF}+$ glucose by $80 \%(P<0 \cdot 001)$. These data underline the essential role of $\mathrm{Ca}^{2+} /$ calmodulin for the growth of pancreatic $\beta$-cells (Table 1).

Protein phosphatases seem to play an important role in HGF-stimulated INS-1 cell proliferation as well. Inhibition of protein tyrosine phosphatases by orthovanadate $(0.5 \mathrm{mM})$ completely inhibited INS-1 cell proliferation, and cyclosporin A $(5 \mu \mathrm{M})$ showed the same effect, completely inhibiting phosphoprotein phosphatase B2 (Table 1).

\section{HGF-mediated mitogenic signal transduction pathways in INS-1 cells}

Protein phosphorylation activation of mitogenic signal transduction pathways by $1.375 \mathrm{nM}$ HGF with or without 3,6 or $15 \mathrm{mM}$ glucose in INS-1 cells was investigated using co-immunoprecipitation and immunoblot analysis. Immunoprecipitation with an anti-phosphotyrosine (PY) antibody followed by immunoblot analysis with anti-PKG antiserum showed an increase in PY phosphorylation of PKC after a $10 \mathrm{~min}$ exposure to $\mathrm{HGF}(1.375 \mathrm{nM})$ in the presence of glucose concentrations up to $6 \mathrm{mM}$ compared with stimulation with glucose alone (Fig. 3). Above $6 \mathrm{mM}$ glucose no additional increase in $\mathrm{PKC}$ activation was seen.

Immunoprecipitation of the $85 \mathrm{kDa}$ regulatory subunit of $\mathrm{PI} 3^{\prime} \mathrm{K}$ (PI3'K p85) followed by immunoblot analysis with antiserum to recognize PKB showed a maximum binding in the presence 
Table 1 The effect of protein phosphorylation inhibitors on glucose- and HGF-stimulated $\left[{ }^{3} \mathrm{H}\right]$ thymidine incorporation in INS-1 cells. Approximately $10^{5}$ quiescent INS-1 cells/well were incubated for $24 \mathrm{~h}$ in RPMI 1640 medium containing 0.1\% BSA, $15 \mathrm{mM}$ glucose, $1.375 \mathrm{nM}$ HGF, various inhibitors of protein kinases, phosphoprotein phosphatases, or tyrosine kinases as indicated, then assessed for proliferation rate by $\left[{ }^{3} \mathrm{H}\right]$ thymidine incorporation as described in Materials and methods. All experiments were done in triplicate on at least five independent occasions. The data are presented as a percentage of either the $\left[{ }^{3} \mathrm{H}\right]$ thymidine incorporation at $15 \mathrm{mM}$ glucose in the absence of HGF or the $\left[{ }^{3} \mathrm{H}\right]$ thymidine incorporation at $15 \mathrm{mM}$ glucose $+1.375 \mathrm{nM} \mathrm{HGF}$, and are means \pm S.E. $(n=5)$. Significant changes are marked $\left({ }^{*}\right)$

\section{Inhibited protein}

\section{Inhibitor}

Control

Wortmannin (10 nM)

PD98059 (50 mM)

Rapamycin (10 nM)

Sphingosine (10 $\mathrm{mM})$

Staurosporine $(20 \mathrm{nM})$

Cyclosporin A ( $5 \mathrm{mM})$

Orthovanadate $(0.5 \mathrm{mM})$

Calmidazolium (50 nM)

-
PI3'K
MAPK
p70 S6K
PKC
PKC, PKA, PKG
Phosphoprotein phosphatase 2B
Protein tyrosine phosphatase
Calmodulin

$\left[{ }^{3} \mathrm{H}\right]$ thymidine incorporation (\%)

\begin{tabular}{|c|c|}
\hline In 15 mM glucose & $\begin{array}{l}\text { In } 15 \mathrm{mM} \text { glucose }+ \\
1.375 \mathrm{nM} \text { HGF }\end{array}$ \\
\hline $\begin{array}{c}100 \cdot 0 \pm 4 \cdot 4 \\
9 \cdot 90 \pm 0 \cdot 7^{*} \\
94 \cdot 5 \pm 5 \cdot 7 \\
33 \cdot 4 \pm 2 \cdot 1^{*} \\
32 \cdot 4 \pm 3 \cdot 6^{*} \\
52 \cdot 8 \pm 3 \cdot 2^{*} \\
27 \cdot 0 \pm 3 \cdot 5^{*} \\
6 \cdot 5 \pm 0 \cdot 7^{*} \\
4 \cdot 6 \pm 0 \cdot 7^{*}\end{array}$ & $\begin{array}{c}100 \cdot 0 \pm 2 \cdot 6 \\
25 \cdot 9 \pm 6 \cdot 2^{*} \\
98 \cdot 7 \pm 3 \cdot 1 \\
50 \cdot 1 \pm 5 \cdot 2^{*} \\
42 \cdot 9 \pm 5 \cdot 4^{*} \\
58 \cdot 3 \pm 3 \cdot 1^{*} \\
31 \cdot 1 \pm 5 \cdot 0^{*} \\
11 \cdot 8 \pm 3 \cdot 0^{*} \\
17 \cdot 9 \pm 6 \cdot 1^{*}\end{array}$ \\
\hline
\end{tabular}

of $1.375 \mathrm{nM}$ HGF and $3 \mathrm{mM}$ glucose. Above this glucose concentration less association was seen in the presence of $\mathrm{HGF}$ but still there was an increased activity compared with $0 \mathrm{mM}$ glucose (Fig. 4). Immunoprecipitation with PI3'K p85 and subsequent immunoblot analysis with the upstream IRS-1 showed a slight increase in IRS-1/PI3'K binding in the presence of $\mathrm{HGF}$ at low glucose concentrations up to $6 \mathrm{mM}$ (Fig. 4), whereas IRS-2/PI3'K binding was not augmented in the presence of HGF (data not shown). Intriguingly, IRS-4 showed an increased binding to PI3' $\mathrm{K}$ in the presence of higher glucose concentrations (maximum binding at $15 \mathrm{mM}$ glucose), whereas in the presence of $\mathrm{HGF}$ an increased PI3'K binding was seen only at low glucose concentrations (Fig. 4).

Immunoprecipitation with anti-PY antibody followed by immunoblot analysis with anti-STAT-5 antisera showed an increased binding after stimulation with $\mathrm{HGF}$ and 0 or $3 \mathrm{mM}$ glucose, which diminished at higher glucose concentrations (Fig. 3). Immunoprecipitation with anti-PY and immunoblotting with anti-STAT-5 showed as well an increased association in the presence of HGF and low glucose concentrations (Fig. 3).

$\mathrm{P} 70^{\mathrm{S} 6 \mathrm{~K}^{\mathrm{S}}}$ is activated downstream of $\mathrm{PI} 3^{\prime} \mathrm{K}$ (Kadowaki et al. 1996). Phosphorylation activation of $\mathrm{p} 70^{\mathrm{S} 6 \mathrm{~K}}$ occurs at multiple sites and can be detected on immunoblot analysis by electrophoresis mobility retardation (Cheatham et al. 1994). Maximal activation occurs 30 min after stimulation (Hügl et al. 1998, 1999). Immunoblot analysis with $\mathrm{p} 70^{\mathrm{S} 6 \mathrm{~K}}$-specific antiserum showed phosphorylation activation in the presence of $\mathrm{HGF}$ with a maximum activation at $3 \mathrm{mM}$ glucose. Above $6 \mathrm{mM}$ glucose, HGF-induced phosphorylation activation of $\mathrm{p} 70^{\mathrm{S} 6 \mathrm{~K}}$ diminished (Fig. 5) whereas stimulation with glucose alone showed maximum activation at $15 \mathrm{mM}$ glucose.

Immunoblot analysis with specific antibodies against phosphorylated MAPK did not show a significant difference after stimulation with HGF (data not shown). Neither did the upstream proteins mSOS (murine sons of sevenless-1 protein) or growth factor-bound protein-2 show an increased binding to Shc and subsequent activation in the presence of HGF (data not shown), indicating that the MAPK pathway does not play an important role in the HGF-instigated proliferation of INS-1 cells.

\section{Discussion}

HGF has been shown to stimulate pancreatic $\beta$-cell proliferation and differentiation (Otonkoski et al. 1994, 1996, Hayek et al. 1995, Vila et al. 1995, Beattie et al. 1996, 1997, Garcia-Ocana et al. 2000). 

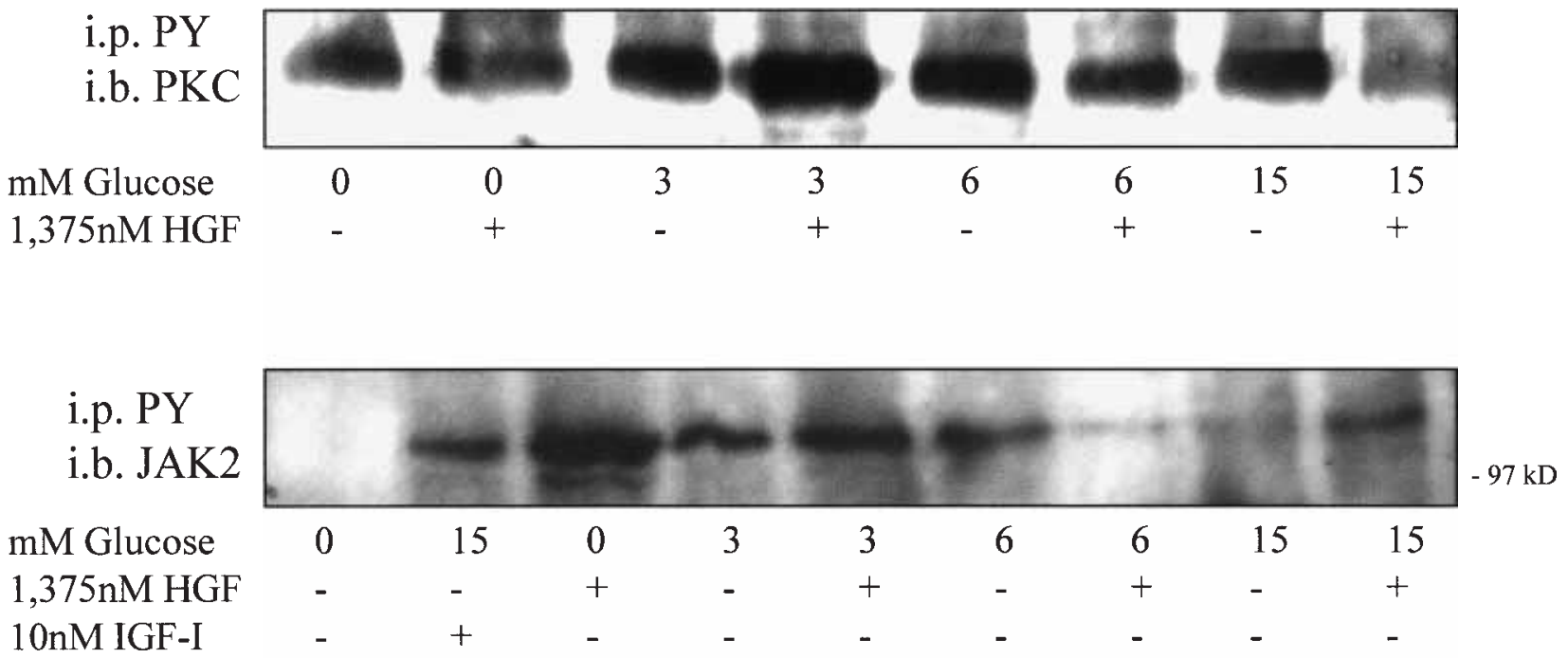

$\begin{array}{llllllllll}\text { mM Glucose } & 0 & 15 & 0 & 3 & 3 & 6 & 6 & 15 & 15 \\ 1,375 \text { nM HGF } & - & - & + & - & + & - & + & - & + \\ 10 \mathrm{nM} \text { IGF-I } & - & + & - & - & - & - & - & - & -\end{array}$

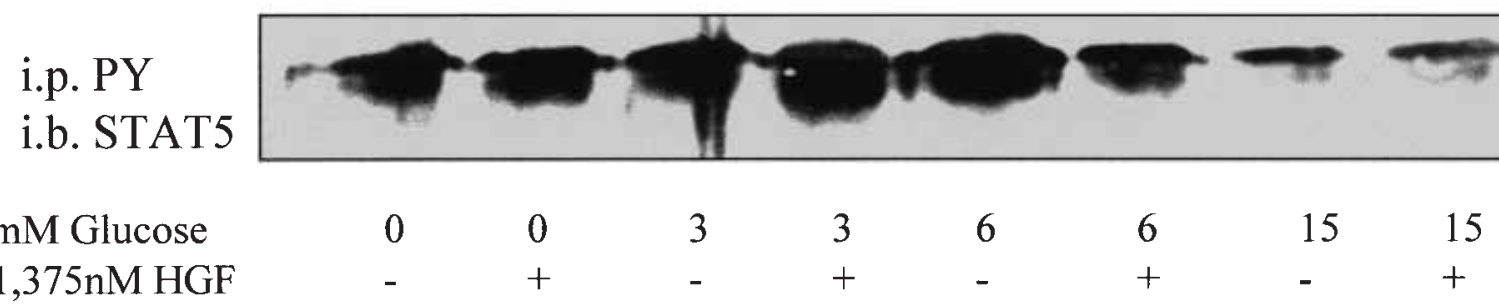

Figure 3 HGF and glucose both increase protein PY phosphorylation of PKC, JAK-2 and STAT-5. INS-1 cells (50\% confluent in a $15 \mathrm{~cm}$ diameter dish) were stimulated with 3-15 mM glucose with or without $1.375 \mathrm{nM}$ HGF for $10 \mathrm{~min}$, and cell lysates generated as outlined in Materials and methods. INS-1 cell lysates were then subjected to immunoprecipitation (i.p.) with antiserum against PY. Immunoprecipitates were then subjected to immunoblot (i.b.) analysis with anti-PKC (upper panel), anti-JAK-2 (middle panel) and anti-STAT-5 (lower panel) antibodies as described in Materials and methods. A representative blot for such co-immunoprecipitation analysis is shown.

However, the HGF-induced mechanisms still remain unclear. In this study, we show that HGF stimulates proliferation of the glucose-dependent $\beta$-cell line INS-1 particularly in the presence of low glucose concentrations (Fig. 1). At higher glucose concentrations the proliferative effect of $\mathrm{HGF}$ above glucose alone diminished from $2 \cdot 2$-fold at $3 \mathrm{mM}$ glucose to $1 \cdot 3$-fold at $24 \mathrm{mM}$ glucose. This differs from the effects of other growth factors like IGF-I or GH where the stimulatory effect was maximal at $15 \mathrm{mM}$ glucose (about 4-fold in IGF-I-stimulated cells) and only about $1 \cdot 5$-fold at low glucose concentrations (Hügl et al. 1998, 1999). Costimulation of INS-1 cells with HGF and IGF-I showed a synergistic increase in $\left[{ }^{3} \mathrm{H}\right]$ thymidine incorporation, which was significant in the presence of glucose concentrations above $12 \mathrm{mM}$ glucose (Fig. 2). It can be speculated whether different growth factors cover different nutritional ranges to secure $\beta$-cell proliferation and that $\mathrm{HGF}$ is mostly active in the presence of physiological or subphysiological glucose conditions whereas IGF-I or $\mathrm{GH}$ are more important in the case of high glucose concentrations. But as these experiments were done in INS-1 cells, further experiments are required before transferring the results to primary cells. For example it might be possible that INS-1 cells show a glucose optimum different from human primary islet cells and that activation of the shown signal transduction pathways occurs at a different glucose range in human cells. But the results suggest that the effect of IGF-I and HGF at least in part activate different signal transduction mechanisms. In contrast, costimulation of HGF and GH shows a different pattern (Fig. 2). Here the increase in cell proliferation was only significant above the 


\section{i.p. PI3' $\mathrm{K}$ \\ i.b. IRS1}

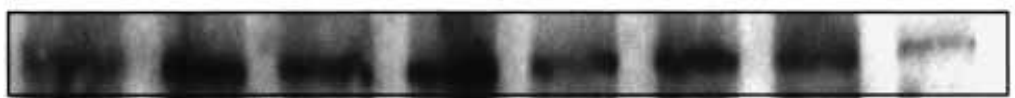

\section{i.p. PI3' $\mathrm{K}$ i.b. IRS4}

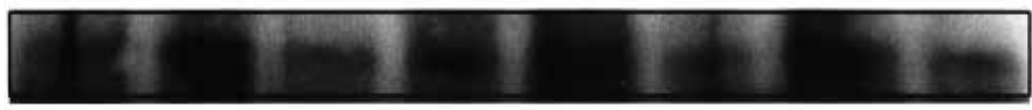

\section{i.p. $\mathrm{PI}^{\prime} \mathrm{K}$ i.b. PKB}

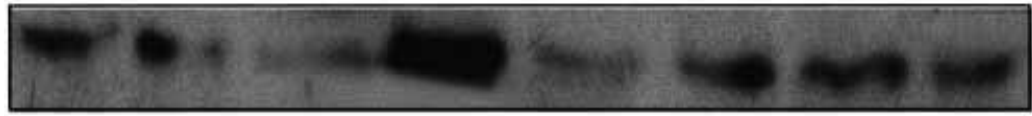

\section{i.p. PI3' $\mathrm{K}$ i.b. PI3'K}

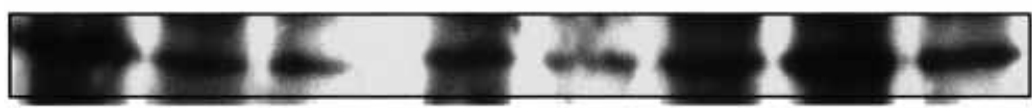

$\begin{array}{lllllllll}\text { mM glucose } & 0 & 0 & 3 & 3 & 6 & 6 & 15 & 15 \\ 1.375 \mathrm{nM} \mathrm{HGF} & - & + & - & + & - & + & - & +\end{array}$

Figure 4 HGF and glucose both increase the association of PI3'K with PKB and IRS-4. INS-1 cells (50\% confluent in a $15 \mathrm{~cm}$ diameter dish) were stimulated with 3-15 mM glucose with or without $1.375 \mathrm{nM} \mathrm{HGF}$ for $10 \mathrm{~min}$, and cell lysates generated as outlined in Materials and methods. INS-1 cell lysates were then subjected to immunoprecipitation (i.p.) with antiserum against the p85 regulatory subunit of $\mathrm{PI} \mathrm{I}^{\prime} \mathrm{K}$. Immunoprecipitates were then subjected to immunoblot (i.b.) analysis with antibodies to IRS-1 (upper panel), IRS-4 (second panel), PKB (third panel) and PI3'K (lower panel), as described under Materials and methods. An example blot for such co-immunoprecipitation analysis is shown.

i.b. $\mathrm{p} 70^{\mathrm{S} 6 \mathrm{~K}}$
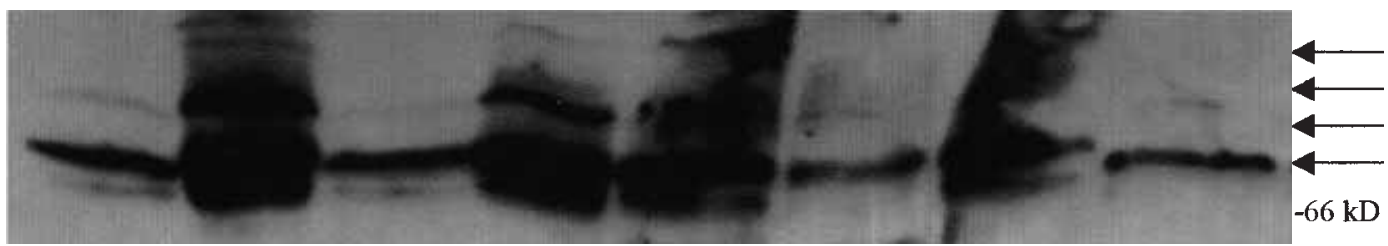

\section{mM Glucose} $1,375 \mathrm{nM}$ HGF

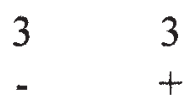

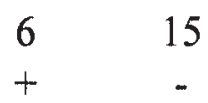

15

$+$

Figure 5 HGF and glucose both stimulate phosphorylation activation of $\mathrm{p} 70^{\mathrm{S} 6 \mathrm{~K}}$ in INS-1 cells. INS-1 cells $(50 \%$ confluent in a $15 \mathrm{~cm}$ diameter dish) were stimulated with 3-15 mM glucose with or without 1.375 nM HGF for $30 \mathrm{~min}$, and cell lysates generated as outlined in Materials and methods. Specific phosphorylation activation of p70 ${ }^{\text {S6K }}$ was examined in the INS-1 cell lysates by immunoblot (i.b.) analysis, as described under Materials and methods. A representative immunoblot for $\mathrm{p}^{\mathrm{S}} \mathrm{S}^{\mathrm{S} 6 \mathrm{~K}}$ is shown. Phosphorylated forms of $\mathrm{p} 70^{\mathrm{s} 6 \mathrm{~K}}$ become retarded on SDS-PAGE analysis, and these multi-phosphorylated $\mathrm{p} 70^{\mathrm{S} 6 \mathrm{~K}}$ forms are indicated by arrows. 
stimulation with $\mathrm{HGF}$ and glucose alone in the presence of low glucose concentrations up to $9 \mathrm{mM}$ glucose. An explanation might be the activation of IRS-4 which is induced by HGF at low glucose concentrations and at high glucose concentrations, but at high glucose concentrations apparently there is no additional activation of IRS-4 (Fig. 4) and therefore no additional increase in proliferation occurs. The other activation seemed to be mediated via activation of the JAK-2/STAT-5 signal transduction pathway, which is the same as seen in GH-instigated cell proliferation (Hügl et al. 1999). In contrast, IGF-I-induced mitogen signal transduction is mediated via IRS-2 (Hügl et al. 1998), which is not activated by HGF and explains the increase in $\left[{ }^{3} \mathrm{H}\right]$ thymidine incorporation after costimulation of INS-1 cells with HGF and IGF-I.

HGF-induced $\beta$-cell proliferation was hereby dependent on PI3' $\mathrm{K}$ activation; inhibition of PI3' $\mathrm{K}$ activity by the specific protein activity inhibitor wortmannin abolished any INS-1 cell proliferation (Table 1). This was an effect similar to that seen in experiments with IGF-I or GH (Hügl et al. 1998, 1999). Inhibition of PI3'K completely abolished INS-1 cell proliferation, which showed no significant differences from non-stimulated $\beta$-cells $(P=0.08$ for glucose-stimulated, $P=0.2$ for cells stimulated with HGF+glucose). Therefore PI3'K seems to have a central role in glucose- and growth factor-stimulated pancreatic $\beta$-cell proliferation. But PI3'K activation by different growth factors occurs via different signal transduction pathways (Krasilnikov 2000, Reddy et al. 2000, Vanhaesebroeck \& Alessi 2000). HGF and GH hereby use the JAK-2/STAT-5 pathway to activate PI3'K whereas IGF-I-induced stimulation is mediated via IRS-2. Interestingly, HGF showed the most effective signal transduction protein activation in the presence of 3-6 $\mathrm{mM}$ glucose, whereas $\mathrm{GH}$ showed an optimum effect in the presence of 6-15 mM glucose (Hügl et al. 1999). This explains why coincubation of HGF and GH only showed a slight but not significant increase in $\left[{ }^{3} \mathrm{H}\right]$ thymidine incorporation, while HGF and IGF-I had a synergistic effect on INS-1 cell proliferation (Fig. 2). Downstream of PI3'K these growth factors all use at least in part similar pathways mediating their mitogenic effects via activation of $\mathrm{p} 70^{\mathrm{S} 6 \mathrm{~K}}$ and $\mathrm{PKB}$ (Figs 3-5) (Cheatham et al. 1994, Myers et al. 1994, Hügl et al. 1998, Dickson et al. 2001).
The MAPK pathway seems to be of less importance in HGF-mediated INS-1 cell proliferation. Inhibition of MAPK activity by PD98059 showed no significant decrease in HGF-stimulated $\beta$-cell proliferation (Table $1, P=0 \cdot 4$ ). HGF did not change the activity of MAPK nor did the upstream signaling proteins (Shc, mSOS, MEK) (data not shown). But still MAPK activation seems to be involved in the activation of IGF-I-mediated INS-1 cell proliferation as a completion in the complex concert of the mitogen signal transduction pathways where a balanced activation is necessary (Dickson et al. 2001). In GH-mediated proliferation, MAPK seems to be of less importance, as seen in HGF-activated cell proliferation (Hügl et al. 1999).

Another important factor in HGF- and glucosemediated $\beta$-cell proliferation is the intracellular $\mathrm{Ca}^{2+}$ level. Inhibition of the calmodulin kinase by calmidazolium leads to a complete inhibition of HGF-stimulated $(88 \%, P<0.001)$ and glucosestimulated $(95 \%, P<0 \cdot 001)$ INS-1 cell proliferation (Table 1). In contrast, IGF-I-stimulated cell proliferation showed no significant decrease in the presence of calmidazolium (Hügl et al. 1998) nor did that of $\mathrm{GH}$ (Hügl et al. 1999). These findings provide evidence that calmodulin-dependent proteins are of importance only for glucose- and HGF-stimulated INS-1 cell proliferation. PKG as well seems to be an important factor in $\beta$-cell proliferation. PKG activation occurred most in the presence of $3-6 \mathrm{mM}$ glucose in the presence of HGF (Fig. 3) while inhibition of PKG by sphingosine significantly decreased INS-1 cell proliferation mediated by glucose $(68 \%, P<0.001)$, HGF $(57 \%, P<0.001)$ (Table 1), IGF-I $(58 \%$, $P<0.001)$ (Hügl et al. 1998) and GH (52\%, $P<0 \cdot 001)$ (Hügl et al. 1999). PKA and PKG activation also seems to be necessary in some way for glucose- and HGF-instigated cell proliferation, as demonstrated by our inhibition studies (Table 1), whereas GH- and IGF-induced cell proliferation does not significantly decrease after inhibition of PKA and PKG by staurosporine (Hügl et al. 1998, 1999) even if these inhibitor experiments should be interpreted with some precautions since these inhibitors are not sufficiently specific. The activation of these signal transduction pathways explains the proliferative effect of $\mathrm{HGF}$ at low glucose concentrations but fails to explain that there is still a proliferation of INS-1 cells in the presence of high glucose concentrations (Fig. 1). 
Further experiments are required to identify the missing links in the mitogenic signal transduction cascades.

In summary this study establishes that HGFinduced signaling transduction via IRS-4 and JAK-2/STAT-5 and subsequent PI3'K activation is present in the pancreatic $\beta$-cell line INS-1. The HGF effect is glucose-dependent and occurs even in the presence of subphysiological glucose concentrations. The MAPK pathway seems to be of less importance for HGF-stimulated $\beta$-cell proliferation. HGF activates similar pathways to glucose, which explains the reduced effect of HGF in the presence of high glucose concentrations. It will be important in future studies to identify the appropriate transcription factors which enable the crosstalk between the different pathways and the signal transduction factors which are activated downstream of PI3'K, PKB and p70 ${ }^{\mathrm{S} 6 \mathrm{~K}}$. Finally, the results have to be transferred to primary cells to find the optimum conditions for human $\beta$-cells.

\section{Acknowledgements}

We thank Dr M G Myers for the anti-IRS antisera.

\section{References}

Asfari M, Janjic D, Meda P, Li G, Halban PA \& Wollheim CB 1992 Establishment of 2-mercaptoethanol-dependent differentiated insulin-secreting cell lines. Endocrinology 130 167-178.

Beattie GM, Rubin JS, Mally MI, Otonkoski T \& Hayek A 1996 Regulation of proliferation and differentiation of human fetal pancreatic islet cells by extracellular matrix, hepatocyte growth factor, and cell-cell contact. Diabetes 45 1223-1228.

Beattie GM, Cirulli V, Lopez AD \& Hayek A 1997 Ex vivo expansion of human pancreatic endocrine cells. Fournal of Clinical Endocrinology and Metabolism 82 1852-1856.

Billestrup N \& Nielsen JH 1991 The stimulatory effect of growth hormone, prolactin, and placental lactogen on beta-cell proliferation is not mediated by insulin-like growth factor-I. Endocrinology 129 883-888.

Boylan JM \& Gruppuso PA 1998 Uncoupling of hepatic, epidermal growth factor-mediated mitogen-activated protein kinase activation in the fetal rat. Fournal of Biological Chemistry $\mathbf{2 7 3}$ 3784-3790.

Brockenbrough JS, Weir GC \& Bonner-Weir S 1988 Discordance of exocrine and endocrine growth after $90 \%$ pancreatectomy in rats. Diabetes 37 232-236.

Cheatham B, Vlahos CJ, Cheatham L, Wang L, Blenis J \& Kahn CR 1994 Phosphatidylinositol 3-kinase activation is required for insulin stimulation of p70 S6 kinase, DNA synthesis, and glucose transporter translocation. Molecular and Cellular Biology 14 $4902-4911$.

Chick WL 1973 Beta cell replication in rat pancreatic monolayer cultures. Effects of glucose, tolbutamide, glucocorticoid, growth hormone and glucagon. Diabetes 22 687-693.
Cousin SP, Hügl SR, Wrede CE, Kajio H, Myers MG Jr \& Rhodes CJ 2001 Free fatty acid-induced inhibition of glucose and insulinlike growth factor-I-induced deoxyribonucleic acid synthesis in the pancreatic ss-cell line INS-1. Endocrinology 142 229-240.

Dickson LM, Lingohr MK, McCuaig J, Hügl SR, Snow L, Kahn BB, Myers MG \& Rhodes CJ 2001 Differential activation of PKB and p70S(super6)K by glucose and IGF-1 in pancreatic beta-cells (INS-1). Fournal of Biological Chemistry $27621110-21120$.

Frodin M, Sekine N, Roche E, Filloux C, Prentki M, Wollheim CB \& Van Obberghen E 1995 Glucose, other secretagogues, and nerve growth factor stimulate mitogen-activated protein kinase in the insulin-secreting beta-cell line, INS-1. Fournal of Biological Chemistry $2707882-7889$.

Garcia-Ocana A, Takane KK, Syed MA, Philbrick WM, Vasavada RC \& Stewart AF 2000 Hepatocyte growth factor overexpression in the islet of transgenic mice increases beta cell proliferation, enhances islet mass, and induces mild hypoglycemia. Fournal of Biological Chemistry 275 1226-1232.

Hayek A, Beattie GM, Cirulli V, Lopez AD, Ricordi C \& Rubin JS 1995 Growth factor/matrix-induced proliferation of human adult beta-cells. Diabetes 44 1458-1460.

Hofmann C, White MF \& Whittaker J 1989 Human insulin receptors expressed in insulin-insensitive mouse fibroblasts couple with extant cellular effector systems to confer insulin sensitivity and responsiveness. Endocrinology 124 257-264.

Hügl SR, White MF \& Rhodes CJ 1998 Insulin-like growth factor I (IGF-I)-stimulated pancreatic beta-cell growth is glucosedependent. Synergistic activation of insulin receptor substratemediated signal transduction pathways by glucose and IGF-I in INS-1 cells. Fournal of Biological Chemistry 273 17771-17779.

Hügl S, Cousin SP, Myers MG Jr, White MF, Reifel-Miller A \& Rhodes CJ 1999 Stimulation of pancreatic beta-cell proliferation by growth hormone is glucose-dependent: signal transduction via Janus kinase 2 (JAK2)/signal transducer and activator of transcription 5 (STAT5) with no crosstalk to insulin receptor substrate-mediated mitogenic signalling. Biochemical fournal 344 649-658.

Jehle PM, Stracke S, Ernst F, Jehle DR, Grunewald RW, Haller H \& Keller F 1998 Pleiotropic effects of hepatocyte growth factor in proximal tubule involve different signaling pathways. Kidney International Supplement 67 S152-S154.

Kadowaki T, Tobe K, Honda-Yamamoto R, Tamemoto H, Kaburagi Y, Momomura K, Ueki K, Takahashi Y, Yamauchi T, Akanuma Y \& Yazaki Y 1996 Signal transduction mechanism of insulin and insulin-like growth factor-1. Endocrine fournal $\mathbf{4 3}$ (Suppl) S33-S41.

Kardalinou E, Zhelev N, Hazzalin CA \& Mahadevan LC 1994 Anisomycin and rapamycin define an area upstream of p70/85S6k containing a bifurcation to histone H3-HMG-like protein phosphorylation and c-fos-c-jun induction. Molecular and Cellular Biology 14 1066-1074.

Khoo S \& Cobb MH 1997 Activation of mitogen-activating protein kinase by glucose is not required for insulin secretion. PNAS 94 5599-5604.

Krasilnikov MA 2000 Phosphatidylinositol-3 kinase dependent pathways: the role in control of cell growth, survival, and malignant transformation. Biochemistry 65 59-67.

Liu JP 1996 Protein kinase C and its substrates. Molecular and Cellular Endocrinology 116 1-29.

Myers MG Jr, Grammer TC, Wang LM, Sun XJ, Pierce JH, Blenis J \& White MF 1994 Insulin receptor substrate-1 mediates phosphatidylinositol 3 '-kinase and p70S6k signaling during insulin, insulin-like growth factor-1, and interleukin-4 stimulation. Fournal of Biological Chemistry 269 28783-28789.

Newgard CB \& McGarry JD 1995 Metabolic coupling factors in pancreatic beta-cell signal transduction. Annual Review of Biochemistry $64689-719$ 
Nielsen JH, Linde S, Welinder BS, Billestrup N \& Madsen OD 1989 Growth hormone is a growth factor for the differentiated pancreatic beta-cell. Molecular Endocrinology 3 165-173.

Ogreid D, Dostmann W, Genieser HG, Niemann P, Doskeland SO \& Jastorff B 1994 (Rp)- and (Sp)-8-piperidino-adenosine 3',5'-(cyclic)thiophosphates discriminate completely between site A and $\mathrm{B}$ of the regulatory subunits of CAMP-dependent protein kinase type I and II. European Fournal of Biochemistry 221 1089-1094.

Otonkoski T, Beattie GM, Lopez AD \& Hayek A 1994 Use of hepatocyte growth factor/scatter factor to increase transplantable human fetal islet cell mass. Transplantation Proceedings 263334.

Otonkoski T, Cirulli V, Beattie M, Mally MI, Soto G, Rubin JS \& Hayek A 1996 A role for hepatocyte growth factor/scatter factor in fetal mesenchyme-induced pancreatic beta-cell growth. Endocrinology 137 3131-3139.

Pang L, Sawada T, Decker SJ \& Saltiel AR 1995 Inhibition of MAP kinase kinase blocks the differentiation of PC-12 cells induced by nerve growth factor. Fournal of Biological Chemistry 270 13585-13588.

Prenki M 1996 New insights into pancreatic beta-cell metabolic signaling in insulin secretion. European Fournal of Endocrinology 134 272-286.

Reddy EP, Korapati A, Chaturvedi P \& Rane S 2000 IL-3 signaling and the role of Src kinases, JAKs and STATs: a covert liaison unveiled. Oncogene 19 2532-2547.

Sjoholm A 1997 Glucose stimulates islet beta-cell mitogenesis through GTP-binding proteins and by protein kinase C-dependent mechanisms. Diabetes 46 1141-1147.
Swenne I 1992 Pancreatic beta-cell growth and diabetes mellitus. Diabetologia 35 193-201.

To CT \& Tsao MS 1998 The roles of hepatocyte growth factor/ scatter factor and met receptor in human cancers (Review). Oncology Reports 5 1013-1024.

Vanhaesebroeck B \& Alessi DR J 2000 The PI3K-PDK1 connection: more than just a road to PKB. Biochemistry 346 $561-576$.

Vila MR, Nakamura T \& Real FX 1995 Hepatocyte growth factor is a potent mitogen for normal human pancreas cells in vitro. Laboratory Investigation 73 409-418.

Welsh M, Mares J, Oberg C \& Karlsson T 1993 Genetic factors of importance for beta-cell proliferation. Diabetes/Metabolism Reviews $\mathbf{9}$ $25-36$.

Withers DJ, Gutierrez JS, Towery H, Burks DJ, Ren JM, Previs S, Zhang Y, Bernal D, Pons S, Shulman GI, Bonner-Weir S \& White MF 1998 Disruption of IRS-2 causes type 2 diabetes in mice. Nature 391 900-904.

Withers DJ, Burks DJ, Towery HH, Altamuro SL, Flint CL \& White MF 1999 IRS-2 coordinates IGF-1 receptor-mediated beta-cell development and peripheral insulin signalling. Nature Genetics 23 $32-40$.

Received 20 November 2001

Accepted 3 December 2001 